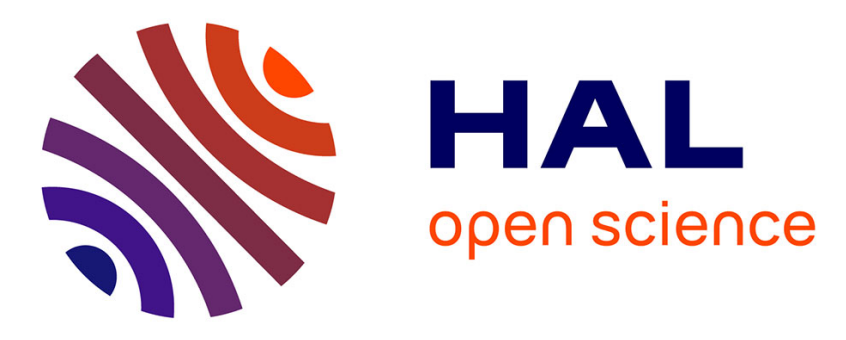

\title{
How do postural parameters vary during walking in asymptomatic adults? A registration technique of subject-specific 3D skeletal reconstruction during gait
} Ayman Assi, Ziad Bakouny, Fares Yared, Joeffroy Otayek, Aren Joe Bizdikian, Ismat Ghanem, Gaby Kreichati, Hélène Pillet, Xavier Bonnet, Wafa Skalli

\section{To cite this version:}

Ayman Assi, Ziad Bakouny, Fares Yared, Joeffroy Otayek, Aren Joe Bizdikian, et al.. How do postural parameters vary during walking in asymptomatic adults? A registration technique of subject-specific 3D skeletal reconstruction during gait. Gait \& Posture, 2018, 65, pp.118-119. 10.1016/j.gaitpost.2018.06.016 . hal-02895840

\section{HAL Id: hal-02895840 \\ https://hal.science/hal-02895840}

Submitted on 10 Jul 2020

HAL is a multi-disciplinary open access archive for the deposit and dissemination of scientific research documents, whether they are published or not. The documents may come from teaching and research institutions in France or abroad, or from public or private research centers.
L'archive ouverte pluridisciplinaire HAL, est destinée au dépôt et à la diffusion de documents scientifiques de niveau recherche, publiés ou non, émanant des établissements d'enseignement et de recherche français ou étrangers, des laboratoires publics ou privés. 


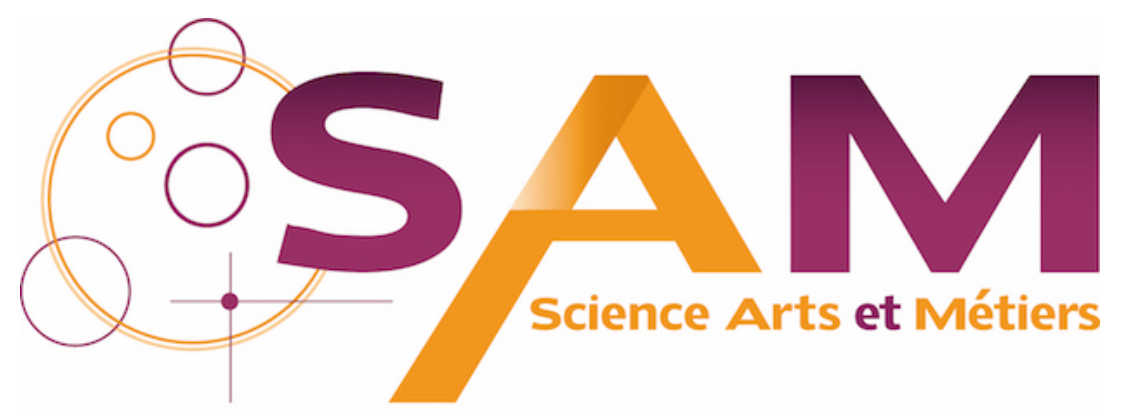

Archive Ouverte - Open Repository

\section{Science Arts \& Métiers (SAM)}

is an open access repository that collects the work of Arts et Métiers ParisTech researchers and makes it freely available over the web where possible.

This is an author-deposited version published in: https://sam.ensam.eu Handle ID: .http://hdl.handle.net/null

\section{To cite this version :}

Ayman ASSI, Ziad BAKOUNY, Fares YARED, Joeffroy OTAYEK, Aren Joe BIZDIKIAN, Ismat GHANEM, Gaby KREICHATI, Hélène PILLET, Xavier BONNET, Wafa SKALLI - How do postural parameters vary during walking in asymptomatic adults? A registration technique of subjectspecic 3D skeletal reconstruction during gait - Gait \& Posture - Vol. 65, nSuppl 1, p.118-119 2018 
Short communication

\title{
O 007 - How do postural parameters vary during walking in asymptomatic adults? A registration technique of subject-specific 3D skeletal reconstruction during gait
}

\author{
A. Assi ${ }^{\mathrm{a}, \mathrm{b}, *}$, Z. Bakouny ${ }^{\mathrm{a}}$, F. Yared ${ }^{\mathrm{a}}$, J. Otayek ${ }^{\mathrm{a}}$, A.J. Bizdikian ${ }^{\mathrm{a}}$, I. Ghanem ${ }^{\mathrm{a}}$, G. Kreichati ${ }^{\mathrm{a}}$, \\ H. Pillet ${ }^{\mathrm{b}}, \mathrm{X}$. Bonnet ${ }^{\mathrm{b}}$, W. Skalli ${ }^{\mathrm{b}}$ \\ ${ }^{\text {a }}$ Faculty of Medicine, University of Saint-Joseph, Laboratory of Biomechanics and Medical Imaging, Beirut, Lebanon \\ ${ }^{\mathrm{b}}$ Arts et Métiers ParisTech, Institut de Biomécanique Humaine Georges Charpak, Paris, France
}

A R T I C L E I N F O

Keywords:

Posture

Gait

Skeletal reconstruction

Image registration

\section{Introduction}

Postural skeletal alignment is altered with age due to intervertebral disc and joint degeneration, consequently affecting quality of life (QoL) and activities of daily living, such as gait. Postural alignment parameters of the spine, pelvis, hips and lower limbs, measured on static standing radiographs, have been widely studied in asymptomatic subjects and subjects affected by various pathologies. However, while most of these parameters are positional and could vary during gait, there are currently no studies investigating how they are modified during walking.

\section{Research question}

How do postural alignment parameters vary during gait in asymptomatic adults?

\section{Methods}

85 asymptomatic adults (age: $29 \pm 4.9$ years [18-59]) underwent gait analysis using the modified Davis protocol [1] with additional markers on the thighs, shanks and C7 spinous process. Subjects then underwent low dose biplanar X-rays in standing position with subsequent subject-specific 3D reconstructions of the spine, pelvis, and lower limbs and calculation of the following 3D radiological postural parameters in the static position: pelvic tilt (PT), sagittal vertical axis
(SVA), acetabular abduction (Acet_Abduction), anteversion (Acet_Anteversion) and tilt (Acet_Tilt) as well as the anterior (Ant_Cov) and posterior (Post_Cov) coverage of the femoral head by the acetabulum $[2,3]$. The $3 \mathrm{D}$ bones were registered on each frame of the gait cycle [4] (Fig. 1). A new technique developed for the purpose of this study, utilizing finite element modeling, was used to reduce soft tissue artefacts. The postural parameters were then computed during the gait cycle, using the 3D registered bones, at each time frame: means and ranges of motion (ROM) were calculated.

\section{Results}

Some of the parameters exhibited large ROM during the gait cycle such as: SVA $(23.3 \pm 7.2 \mathrm{~mm})$, Acet_tilt $\left(17.8 \pm 7.3^{\circ}\right)$, Acet_Abduction $\left(10.9 \pm 3.5^{\circ}\right)$, and coverage of the femoral head anteriorly and posteriorly $(9.3 \pm 1.7 \%)$. Acet_Anteversion had a lower ROM $\left(3.4 \pm 1^{\circ}\right)$. Fig. 2 shows the variation of the postural parameters during the gait cycle as corridors of normality (mean \pm SD) with the value of the static radiological parameter represented for comparison. During walking, all the parameters varied around their standing posture value, except for the SVA which was shifted anteriorly $(25 \mathrm{~mm})$ and PT which was slightly increased by $2^{\circ}$.

\section{Discussion}

This is the first study to describe variation of postural parameters

\footnotetext{
* Corresponding author at: Faculty of Medicine, University of Saint-Joseph, Laboratory of Biomechanics and Medical Imaging, Beirut, Lebanon.

E-mail address: ayman.assi@gmail.com (A. Assi).
} 


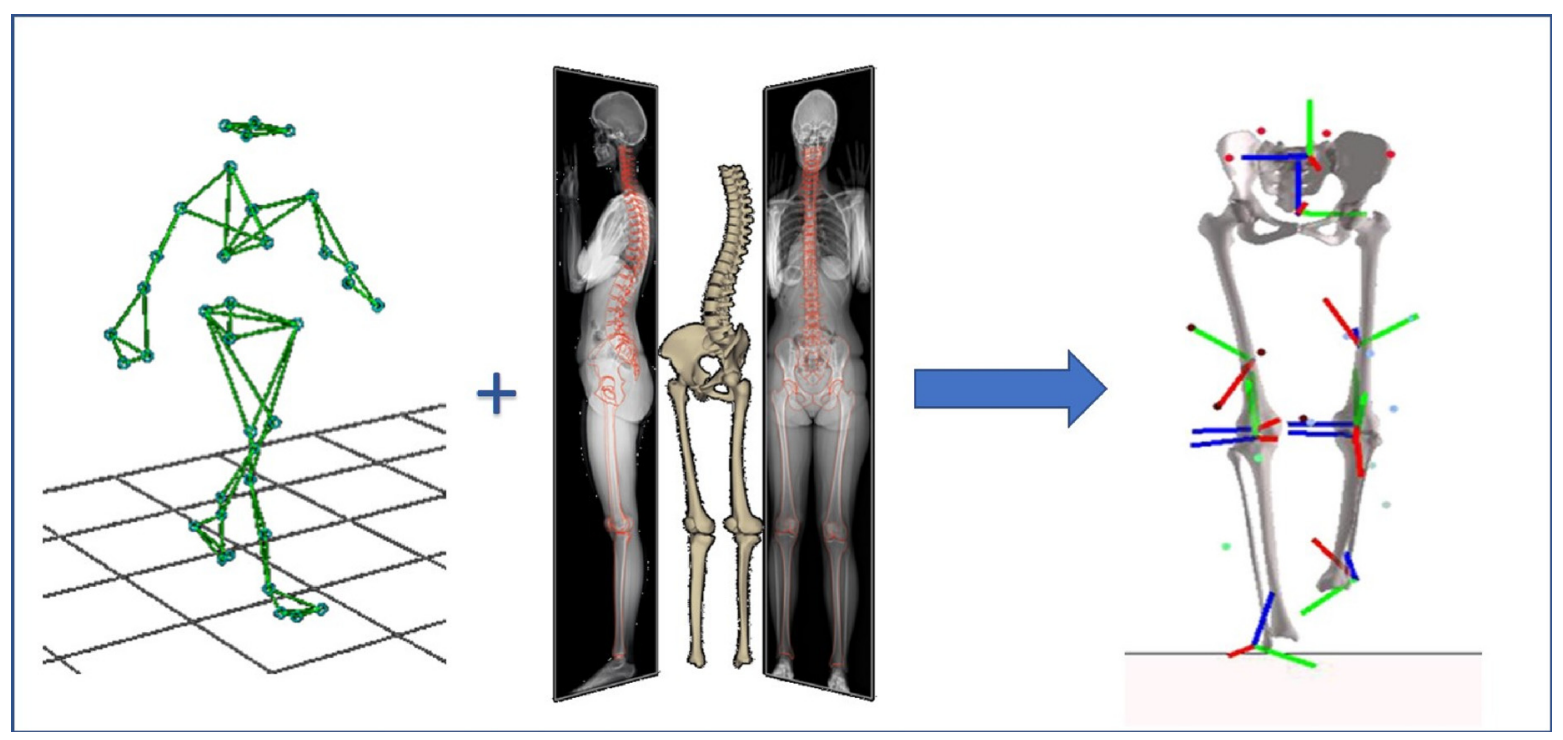

Fig. 1. Registration technique of 3D skeletal reconstruction from biplanar x-rays with gait analysis.

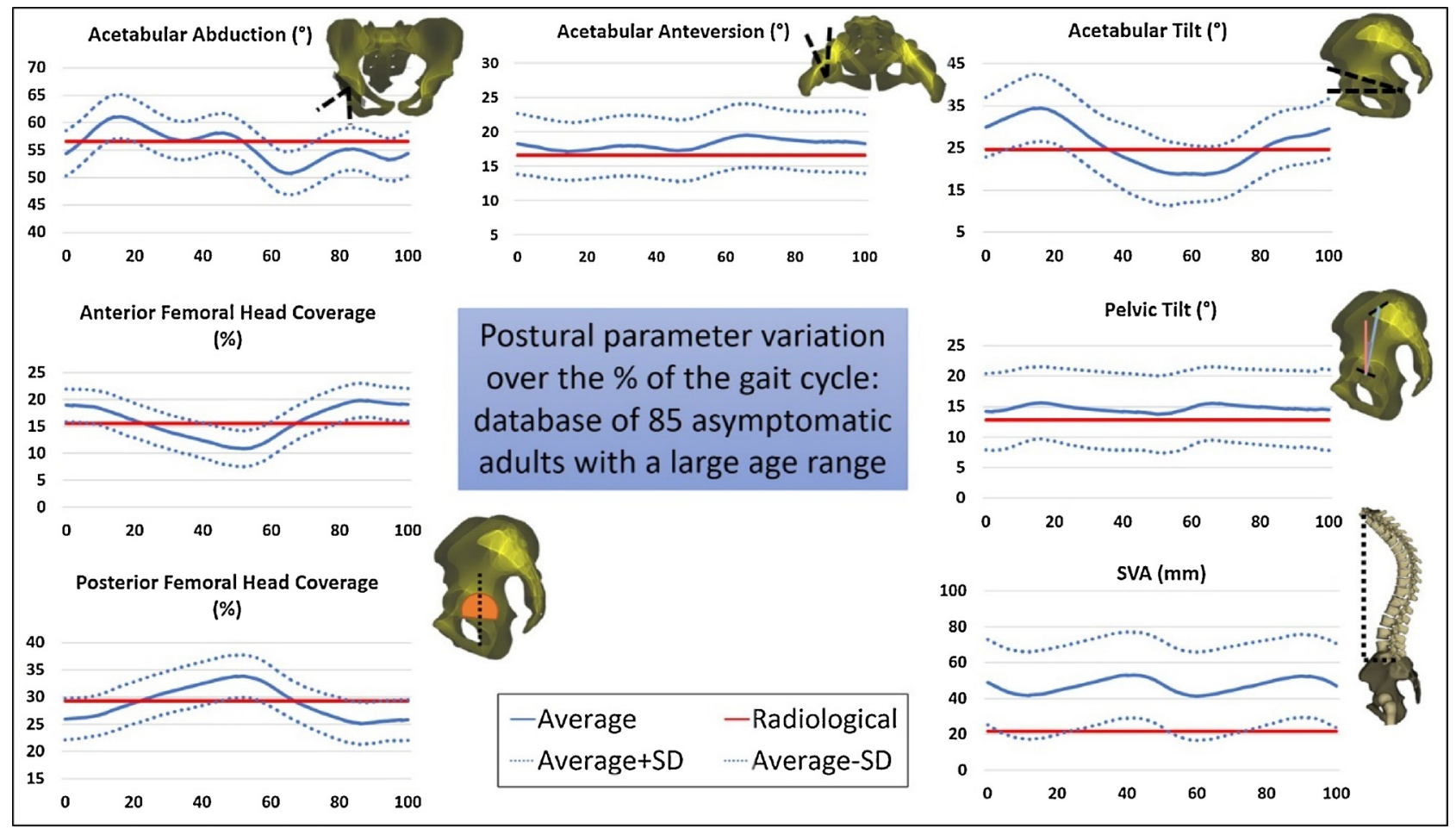

Fig. 2. Variation of 3D postural parameters during gait.

during walking. The variation of acetabular parameters during gait is indicative of the potential change of acetabular cup positioning in total hip replacement during walking. Furthermore, the anterior shift and large ROM of SVA during walking emphasizes the importance of considering the dynamic variation induced by gait when planning surgical re-alignment of the spine. The findings of this study could also provide quantitative data for gait biomechanical modelling.

\section{References}

[1] Davis et al., 1990

[2] Ames et al., 2012.

[3] Ghostine et al., 2016.

[4] Söderkvist et al., 1993. 